\title{
OTONOMI DAN DESENTRALISASI BERTERASKAN ILMU DAN WAHYU?
}

Oleh: Husain Haikal

\section{Abstract}

Entering the third millenium, the Indonesian government is carrying out autonomy and decentralization programs. The aim of these sudden programs is creating more realistic and just situation. However, the situations are getting worse as ethnic cleansing, misused of power, and separatist movements are becoming daity realities. This is due to the fact that since the fifties the Indonesian central government gradually pays little attention to the education and health programs. Moreover, the central government has no serious attempts to create the real middle class and private sectors in addition to carrying the rule of the law. Through this limited available space, this article tries to highlight the first core for the successful autonomy and decentralization by providing good education, based upon science and revelation, for the Indonesians as a whole, especially for the young generation.

في العصر ألفى الثالث كانت حكومة إندونيسيا تنفذ منهاج الملكم الذاتي في جميع

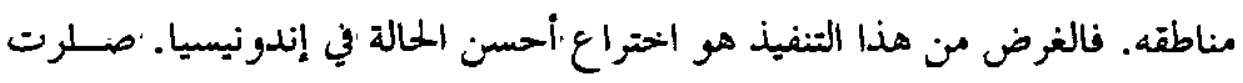

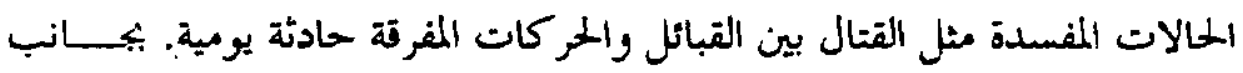

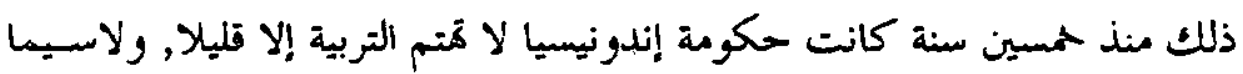

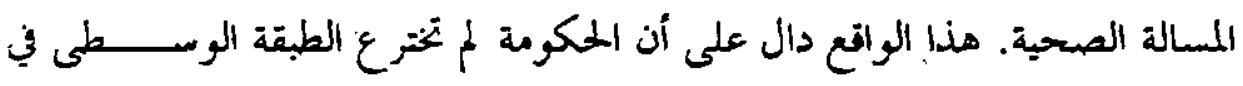

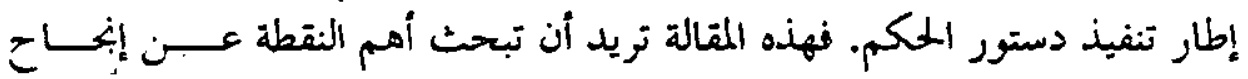

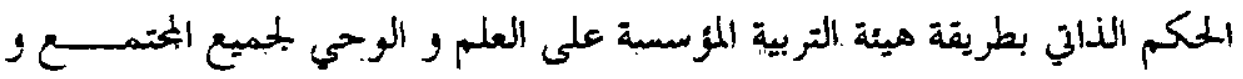
لكأجيال الثيأبة خحصوصا. 
aku terkejut ketika kaca mobilku di-ketuk oleh jari-jari kecil. Di luar hujan deras. Lewat kaca yang remang-remang aku melihat anak kecil yang menggigil kedinginan. Tubuhnya basah kuyup. Arlojiku menunjukkan pukul dua dinihari. $\mathrm{nPak}$, ini tauco seribu tiga. Beli, pak, buat bayar uang sekolaho, suaranya yang parau. ${ }^{1}$

\section{A. Pendahuluan}

Lukisan di atas merupakan realita yang menyayat di salah satu perempatan jalan di Cianjur yang direkam Kang Jalal, yang terjadi setelah Indonesia mampu membangun berbagai fasilitas yang cukup mempesona. Diharapkan ketimpangan di atas tidak lagi berlaku setelah otonomi dan desentralisasi beriaku secara bermakna sejak awal tahun 2001. Nampaknya cita-cita ini belum sejalan dengan realita yang ada, bahkan sulit memberikan jawaban apakah kebijakan pemerintah mengenai otonomi dan desentralisasi merupakan peluang atau beban. Untuk sementara propinsi, maupun daerah kabupaten dan kota yang kaya, relatif belum merasakan problema yang mendesak. Yang wujud di daerah yang beruntung itu justru problema yang dibuat mereka sendiri, sejenis dimunculkan kaedah baru yang mengharuskan mereka yang berperan adalah mereka yang diberi label sebagai putera daerah. 'Secara normatif, ada semacam usaha menghidupkan budaya ashabiyah, sebagai sesuatu nilai yang separutnya perlu dijauhi. ${ }^{2}$ Dalam kaitan ini cukup mencabar sajian berikut ini:

Ada kecenderungan umum untuk memaknai putra daerah terbatas dalam pengertian mereka yang lahir di daerah itu, dan mempunyai nenek moyang yang juga berasal dari daerah tersebut. Artinya, mereka yang hanya memiliki salah satu dari kriteria itu termasuk kategori bukan putra daerah, alias pendatang. . . . ..................................................... ketentuan seperti itu, mereka yang ternyata termasuk bukan putra daerah atau pendatang perlu segera dikurangi perannya dalam birokrasi pemerintahan, kalaupun tidak segera disingkirkan. Itu dilakukan dengan semangat kedaerahan yang tinggi, tanpa mencermati apakah kualitas putra daerah yang dicalonkan sudah memadai untuk tugas yang diembannya. ${ }^{3}$

\footnotetext{
1 Jalajuddin Rakhmat, 1998, Islam Aktual, Mizan, Bandung, hal. 182. Realita ini mengungkap berbagai ketimpangan yang berlaku sejak zaman orla, serta makin berambah parah pada masa orba. Ada sebagian anggapan kenyataan yang pincang ini dinilai diabaikan kaum cendekiawan. Sebenanya sejak zaman orla dan orba sebagian cendekjawan bekerja keras melontarkan berbagai gagasan agar dilakukan pembangunan politik secara bermakna, pernbaharuan politik yang menguntungkan semua pihak. Untuk lebih jelasnya lihat antara lain Arbi Sanit, 1998, Reformasi Politik, Pustaka Pelajar, Yogya.

${ }^{2}$ Dalam kaitan ini perlu direnungkan apa yang dipesankan Rasulullah Saw.: nBukan dari kami siapa yang mengajak kepada ashabiyah, bukan juga berperang atas dasar ashabiyah, bukan juga yang mati dalam keadaan [mendukung] ashabiyaho. (H.R. Abu Dawud) Selanjutnya lihat M. Quraish Shihab, 1996, Wawasan al Qur'an, Mizan, Bandung, hal. 338-9.
} 
Lahirnya kebijakan sejenis otonomi dan desentralisasi telah membuat berbagai negara lain maju secara bermakna. Otonomi dan desentralisasi merupakan suatu kemestian, sekiranya Indonesia ingin menyongsong modernisasi secara utuh. Tetapi otonomi dan desentralisasi saja hanya akan mengundang problem-problem lain, apalagi semua itu tanpa direncanakan secara matang dan diperlakukan secara bertahap. Dalam kaitan ini sah-sah saja sekiranya kita mau bercermin pada Jepang, sehingga mereka tampil sebagai bangsa yang terhormat dalam panggung sejarah dunia. Untuk lebih jelasnya tolong dikaji uraian 'saran atau nasehat' Yukichi berikut ini:

... [Jepang] belum lagi mencapai tingkat negara-negara barat dalam bidangbidang ilmu pengetahuan, wiraswasta, dan hukum. Tetapi sebenarnya suatu peradaban modern buat sebagian terbesar dibangun di atas tiga landasan ini. Kalau tidak tercapai suatu kemajuan yang wajar dalam ketiga bidang ini, jelasnya bahwa kemerdekaan nasional tidak mungkin dipertahankan. ${ }^{4}$

Untuk kebangkitan kembali Indonesia secara terhormat di panggung sejarah dunia, selain menata kembali pendidikan, wiraswasta, hukum, ada hal tak kalah pentingnya untuk dibenahi. Terasa penting sekali perlunya peningkatan pelayanan dan mutu kesehatan bagi siapa saja yang memerlukan. Hal ini sejalan puia dengan apa yang disajikan dalam amanat proklamasi dan Pembukaan UUD 1945 yang antara lain menekankan:

. . . untuk membentuk suatu pemerintah negara Indonesia yang melindungi segenap bangsa Indonesia dan seluruh tumpah darah Indonesia dan untuk memajukan kesejahteraan umum, mencerdaskan kehidupan bangsa, dan ikut melaksanakan ketertiban dunia yang berdasarkan kemerdekaan, perdamaian abadi dan keadilan sosial . . .

Dengan berbagai keterbatasan yang ada, artikel ini akan mencoba menyajikan berbagai problema yang berkaitan dengan otonomi dan desentralisasi. Untuk mengatasi hal itu kunci utamanya adalah perbaikan pendidikan yang sejak merdeka terabaikan. Paling mudah hal ini tercermin dengan minimnya dana pendidikan yang disediakan, sedangkan sejak diletakkan fondasi orba telah dibuat TAP MPRS No. XXVII/1966 yang menetapkan anggaran pendidikan sebesar $25 \%$. Keputusan yang harus ditaati sepenuhnya dengan kenyataan yang ada, terasa sebagai jurang yang menganga secara tajam, karena anggaran pendidikan Indonesia tidak pernah melampaui $7 \% .^{5}$

${ }^{3}$ Lihat Sjafri Sairin, 2001. "Otonomi Daerah: Jerat-jerat Kultural", Gatra, 3 Maret, hal. 82. Dalam kaitan ini ada baiknya dibaca komentar berikut ini: “[Kebijakan ini telah melahirkan] . . . parochial decentralizarion dengan adanya konsep putra daerah, bukan desentralisasi yang sadar pasar market conscious decentralizarion. Dengan konsep sempit seakan-akan anak yang lahir akan dididik di tempat dia dilahirkan, mencari nafkah di situ, demikian pula saat pensiun sehingga wafat nantinya. (Lihat selanjunya T. Raka Joni, 2001, "Permasalahan Kritikal Pengelolaan Ketenagaan Guru dalam Kerangka Pikir Desentralisasi", Seminar Komisi Reformasi Pendidikan Nasional 16-17 Maret, hal. 9.)

"Yukichi Fukuzawa, "Encouragement of Learning", alih bahasa Arifin Bey, Jepong Di antara Feodalisme don Modemisasi, Pantja Simpati. Jakana, hal. 55 


\section{B. Otonomi, Desentralisasi dan Problemanya}

Apakah yang disebut otonomi dan disentralisasi? Nampaknya keduanya merupakan satu paket yang tidak dapat dipisahkan. Tidak mungkin dilaksanakan otonomi tanpa dilaksanakan desentralisasi atau pembagian wewenang. Otonomi daerah adalah kewenangan daerah otonom untuk mengatur dan mengurus kepentingan masyarakat setempat menurut prakarsa sendiri berdasarkan aspirasi masyarakat sesuai dengan peraturan perundangan-undangan. Ini menekankan prinsip-prinsip demokrasi, peran serta masyarakat, pemerataan, dan keadilan, serta memperhatikan potensi dan keanekaragaman daerah. Otonomi yang luas dan utuh berlaku di daerah kabupaten, dan kota; sedangkan otonomi propinsi merupakan otonomi terbatas. ${ }^{6}$ Digulirkan otonomi dan desentralisasi telah melahirkan kesadaran palsu karena melihat ini sebagai suatu peluang, tetapi selama ini peran serta mereka yang berwewenang di daerah lebih bersifat pasif, menunggu, bahkan masih tergantung pusat, terutama dalam hal yang berkaitan dengan kewajiban.

Realita yang memprihatinkan ini merupakan cerminan budaya orba yang khas. Terbukti sepanjang sejarah orba elit politik nasional membuat keputusan tanpa mempertimbangkan dukungan dan tidak mencari simpati daerah demi kelangsungan politik nasional. Lebih celaka lagi arena politik lokal dimonopoli atau dibelenggu pemikiran elit pusat.' Akibatnya dalam pelayanan publik lebih memberhalakan prosedur, dan penyimpangan boleh terjadi kalau menguntungkan pihak yang di atas sekalipun sangat merugikan masyarakat pengguna.Umumnya warga karena terdesak waktu, atau harus bekerja, terpaksa mengeluarkan uang pelicin agar dapat dilayani dengan baik dan cepat. $^{8}$

Apabila telah mantap otonomi berarti suatu daerah mempunyai a. kewenangan mengatur dirinya sendiri $b$. kemandirian dalam mengatur dan mengurus dirinya sendiri, dan $\mathrm{c}$. tidak tergantung pada pihak lain, dalam arti pemerintah pusat tidak mempengaruhi serta mengintervensi suatu kebijakan daerah. Inilah wacana lisan yang ditampilkan, hanya saja daiam praktek masih dapat dipertanyakan lagi.

\footnotetext{
${ }^{3}$ Ahmad Syafii Maarif, 2001, "Landasan Pendidikan Indonesia Masa Depan", Makalah Disampaikan dalam Seminar Reformasi Pendidikan Nasional, di UNY, 16-17 Maret, hal. 1

t" "Pendahuluan". dalam Dadang Yuliantara (Penyuning), 2000. Arus Bawah Demokrasi, Yogya: Lepara Pustaka Utama. hal. ix-x. Ada baiknya apabila pendapat ini dibandingkan dengan definisi lainnya. Salah satu diantaranya menyajikan bahwa otonomi adalah hak dan kewenangan yang diberikan pihak yang berwewenang atau pemerinah kepada suan lingkungan masyarakat, himpunan atau badan resmi lain untuk menyelenggarakan fungsinya secara mandiri selama hal tersebus tidak bertentangan dengan undang-undang, peraturan yang berlaku secara-umum. Tentunya ada beragam bentuk otonomi, atau sekurang-kurangnya ada berbagai tahapannya.

'Pratikno. 1999, "Hubungan Pusat Daerah Pasca Orba Analisis Awal terhadap UU No. 22/1999 dan RUU No. 23/1999 , makalah dalam diskusi panel KMAN Fisipol UGM, 27 Mei, hal.6
} 
Agar otonomi daerah dapat berhasil secara bermakna, harus dimantapkan landasan teori, tujuan, dan diketahui faktor pendukung dan penghambatnya serta berbagai potensi yang terpendam yang dimiliki suatu daerah kabupaten, kota, atau propinsi. Sedangkan landasan hukumnya terwujudkan dalam UU No. 22 th. 1999 , UU No. 25 th. 1999 , UU No. 26 th. 1999 , dan peraturan pemerintah No. 25 th 2000, serta PP No. 84 th 2000. UU No. th. 1999 tentang pemerintahan daerah, dan UU No. 25 th. 1999 tentang Perimbangan Keuangan antara Pemerintah Pusat dan Daerah. Bagaimana paradigma yang dianut? Apakah akan mengikuti paradigma 'Barat', atau yang lainnya umpamanya paradigma 'Timur'. Langkah-langkah selanjutnya akan berpihak pada elit ataukah populis."

Selama berkuasa, Soeharto melakukan pendekatan yang kental sekali aroma elitnya, terasa betapa mempesonakan gedung-gedung megah yang berhasil dibangun. Hanya saja banyak pula anggota masyarakat bawah yang makin terpinggirkan dan hak-haknya terabaikan sama sekali. Untuk lebih jelasnya nampak dalam uraian ini:

Bila kita keluar dari Bandara Soekarno-Hatta lewat jalan layang ke Jakarta, lihatlah ke kanan dan ke kiri, di bawah jalan layang yang megah itu. Tiba-tiba mata kita akan menatap pemandangan yang memilukan. Beribuan rumah yang berjubel, sebagian reyot, compang-camping dan kebanyakan tidak layak huni segera 'menyengat' mata dan nurani kita. Memang gedung-gedung jangkung yang hebat dan modern juga terlihat dari jalan layang yang baru dibuka itu, tetapi matı tidak mau nurani kita segera tertusuk oleh sebuah kontras. ${ }^{10}$

Semua realita yang demikian pincang tersebut merupakan sebuah lukisan keserakahan para pendukung kapitalisme, sehingga lahirlah the greedy state. Wajarlah apabila Hatta secara tajam menyoroti kelemahan kapitalisme dan menawarkan alternatif obatnya dengan memantapkan koperasi yang berorientasi populis dan tidak diintervensi pihak penguasa seperti tercermin dalam kebijakan koperasi selama Orde Lama dan Orde Baru. Upaya Hatta, merupakan pemahamannya yang mantap dan utuh tentang Islam. Sebagai addin yang lengkap, Islam menawarkan leveling proces yang harus dilaksanakan tanpa ditunda-tunda lagi. Akibatnya, praktek monopoli,

"C.f. Agus Dwjyanto, 2000, "Membangun Sistem Pelayanan Publik yang Memihak pada Rakyat", makalah Seminar Nasional Profesionalisasi Birokrasi dan Peningkatan Kinerja Pelayanan Publik, diselenggarakan Jurusan Imu Administrasi Negara, Fisjpol UGM , 29 April, hal. 6-8

- Tentang pendekatan populis lihat antara lain Jalaluddin Rakhunat, 1998, Islam Alremarif. Mizan, Bandung, hal. 243 dan 247; serta Kuntowijoyo, 1985, Dinamika Sejarah Umat Islam Indonesia, Shajahuddin Press, Yogya, hal. 7

1" Refleksi Amien Rais, 1997, Jakarta: Gema Insani Press, hal. 127. Ketimpangan yang demikian menyolok inj telah melontarkan penilaian kritis sebagai berikut: Kilas balik yang dapat kita lihat bahwa selama lima puluh tahun berdirinya negara ini, terutama dalam kurun waktu Orde Lama (1959-1965) dan Orde Baru (1966-1998) rakyat Indonesia mengalami era penindasan baru yang tragisnya dilakuian oleh penguasa bangsanya sendiri. Kebebasan dan hak-hak warga negara dirampas, ketidakadilan menjalar dalam berbagai bidang, seperti idiologi, politik, ekonomi. 
monopsoni, dan oligopoli harus dicegah sejak dini, sedang yang telah berjalan harus dikikis habis secara bertahap. ${ }^{11}$ Sedang Soekarno pada masa penjajahan telah mengingatkan bahaya kapitalisme dengan uraiannya berikut ini:

. . . bangsa yang dikungkung oleh kapitalisme yang terpecah-belah di dalam kelas-kelas yang memusuhi satu sama lain, akan menunjukkan di dalam onderwijs [pengajaran]nya semua perpecah-belahan, semua pertikaian dan percideraan, semua nafsu-nafsunya penderitaan ${ }^{2}$ dan perjuangan, semua kuman-kumannya divide et impera [pecah-belah dan kuasai] yang asalnya dari kungkungan kapitalisme itu. ${ }^{12}$

Sedangkan salah satu contoh pendekatan populis dengan bernakna telah berhasil dilaksanakan Malaysia dan Iran pada masa pasca Shah Reza. Untuk lebih jelasnya dapat dilihat uraian hasil pemerataan model Iran berikut ini:

Usaha pemerataan itu dapat dilihat dengan kasat mata, tanpa melihat angkaangka statistik yang bagi orang awam sering cenderung ruwet.

Masyarakat Teheran ... dapat dikatakan mencerminkan masyarakat yang cukup egalitarian. Sulit sekali menemukan mobil-mobil mewah bersliweran di jalanjalan raya seluruh Teheran. Pada umumnya mobil di Teheran seragam dalam keadaan sederhana. Juga sulit dicari hotel-hotel yang bergebyaran dengan segala kemewahan. Toserba yang gemerlapan yang memacu konsumerisme juga tidak nampak. Bahkan jalan layangnya juga kelihatan sederhana.

Akan tetapi pada saat yang sama kita melihat bagaimana semua penduduk berpa-kaian rapi dan necis. Saya bahkan tidak pernah melihat kaum gelandangan atau pengemis di Teheran. Saya bisa saja keliru, tetapi tiga kali berkunjung ke Iran dan menelusuri perkampungan di sana, terutama di ibukotanya, saya tidak berhasil menemukan gubuk reyot atau komplek gubuk reyot yang compang camping dan kumuh serta memilukan. ${ }^{13}$

Dalam Psl 2, PP 25 th. 2000 dikatakan: "Yang menjadi wewenang pemerintah pusat setelah berlakunya otonomi adalah bidang politik luar negeri, pertahanan dan keamanan, peradilan, moneter dan fiskal, agama serta kewenangan bidang lain." Potongan kalimat: “. . . kewenangan bidang lain” apabila tidak diuraikan secara jelas dapat menjadi 'jebakan' dalam melaksanakan otonomi secara bermakna.

'Jebakan' lain adalah peraturan yang dibuat DPRD setempat seperti keharusan kedudukan puncak harus diberikan non-TNI serta mereka yang menang dalam pemilu. Apalagi kalau semua ini disajikan dan dipahami serta dimaknai secara ketat. Hal ini terjadi karena seorang penguasa belum dibedakan dengan seorang pemimpin. Secara mudahnya seorang penguasa lebih

dan sosial budaya. (Lihat Gatot Wijayanto, 2000, “Aparamr Yang Bersih, Pemimpin Yang Rela Berkorban dan Menderita Kunci Keberhasilan Otonomi Daerah", Makalah Seminar Pati Menyongsong Otonomi Daerah Tahun 2001, pada 20 Nov.. hal. 2 )

"M. Amien Rais, 1997, Demi Kepentingan Bangsa. Pustaka Pelajar, Yogya. hai. 43 
mendahulukan hak dan sering melupakan kewajiban yang harus diembannya. Berbeda dengan penguasa, seorang pemimpin selalu lebih mementingkan kewajiban dan sangat memegang amanat yang diembannya serta cenderung mendahulukan wujudnya hak-hak bawahan atau kesejahteraan mereka yang dipimpinnya. Seseorang pemimpin hanya mau menerima haknya setelah semua orang yang dipimpinnya menerima hak masing-masing secara penuh.

Selama berada di kursi kekuasaan atau jabatannya, seorang penguasa sering digoyang-goyang atau dituntut untuk segera lengser. Kecuali kroni dan keluarga penguasa, umumnya rakyat bergembira saat penguasa harus pensiun atau dilengserkan. Ini mudah dimengerti karena mayoritas rakyat menderita atau dirugikan selama sang penguasa 'bertengger' di kursi kekuasaannya. Salah satu contoh rakyat yang dirugikan oleh akal-akalan sebagian penguasa dan pengusaha dapat dilihat dari uraian berikut ini:

Bisakah kita mengambil pelajaran dari PT. Freeport Indonesia di Irian Jaya? Perusahaan tambang Amerika ini sejak 1973 telah menambang emas, perak dan tembaga di Irian Jaya. Sekarang ini setiap hari, secara harfiah setiap hari, 125.000 ton bijih tambang diruntuhkan dari gunung-gunung di pegunungan Jaya Wijaya. Dari jumlah bijih tambang sekian in, diperoleh konsentrat sekitar 6.000 ton. Setiap ton konsentrat mengandung $300 \mathrm{~kg}$ tembaga, 60 gram perak dan 30 gram emas. Walhasil, selama seperempat abad, kekayaan bangsa yang sudah digotong keluar negeri kurang lebih 1620 ton emas, 3420 ton perak dan 162 juta ton tembaga. Sekian ton emas itu, kalau dirupiahkan dengan harga sekarang [1997] bernilai lebih dari 400 trilyun rupiah. Tahun 1991 Freeport sudah mengantongi izin penambangan lagi untuk masa 30 tahun ditambah dua kali sepuluh tahun (dus, setengah abad) dengan wilayah eksploitasi yang lebih luas lagi. ${ }^{14}$

Berbeda dengan penguasa, seorang pernimpin hidup 'menderita' dengan amanah yang diembannya. Hanya selama pemimpin diberi wewenang, umumnya rakyat hidupnya tenteram dan bahagia sekalipun belum mendapatkan haknya secara utuh. Sekurang-kurangnya mereka mempunyai harapan sekalipun masih dalam keadaan memprihatinkan. Keadaan yang belum menguntungkan ini sebagai dampak dari berbagai kebijakan pahit yang 'merugikan' untuk jangka pendek tetapi menguntungkan dalam jangka panjang. Begitu seorang pemimpin berhenti atau pensiun, sebagian besar rakyat meratapinya. ${ }^{15}$ Biasanya para penguasa saja

12 Di Bawah Bendera Revolusi, Jilid I, hal. 615. Kutipan ini, seperti kutjpan-kutipan yang menggunakan ejaan lama serta sejenisnya, diselaraskan dengan E. Y. D.

12 Refleksi Amien Rais, hal. 126-127

${ }^{14}$ Ibid., hal. 24-25.

${ }^{15}$ Sepanjang sejarah Indonesia modern penuh ditaburi contoh para pemimpin seperi Pangsar Soediman. Pak Nas. Bung Harta, Roem, Kasman, Hugeng, Natsir, Hasyim Asy'ari, Ahmad Dahlan, Ki Hadjar Dewantara, Engku Syafei, Rahmah el Yunusiah, dan Hamka. Belum lagi para pemimpin tingkat lokal seperti Abdullah Hinduan, Pak Zar, Pak Sahal, Pak Kromorejo. Jurah Condong Carur. Sepanjang sejarah Islam muncul berbagaj pemimpin yang abadi seperti Abubakar dan Umar. Ali, Umar îbn Abdul Aziz. Unuk riwayat Abubakar dan Umar a.l. dapar dikaji dari tulisan Thaha Husain, "Asy Syaikhan", a.b. Ali Audah, 1986, Dua Tokoh Besar Dalam Sejarah Islam, Pustaka Jaya, Jakara. 
yang lebih dikenal, sekiranya disetujui kalimat berikut:

... "sejarah adalah milik orang-orang yang menang" yang menjadi momok bagi dunia pendidikan. Dunia pendidikan yang selalu mendapat kooptasi dari lingkungan politik akan menyebabkan adanya manipulasi pendidikan yang pada gilirannya akan memanipulasi sejarah. ${ }^{16}$

Yang perlu diperhatikan pula UU No. 22 th 1999 Pasal 6 ayat 1 yang berbunyi: "Daerah yang tidak mampu menyelenggarakan otonomi daerah dapat dihapus dan/atau digabung dengan daerah lain." Menurut UU No. 22/ 1999 Pasal 11 ayat 2 Bidang pemerintahan yang wajib dilaksanakan oleh daerah kabupaten dan daerah kota meliputi pekerjaan umum, kesehatan, pendidikan dan kebudayaan, pertanian, perhubungan, industri dan perdagangan, penanaman modal, lingkungan hidup, pertanahan, koperasi dan tenaga kerja.

Dari realita yang telah berjalan, nampak jelas ide otonomi lahir dan berkembang secara tergesa-gesa sekalipun benih awalnya telah disemaikan dalam UUD 45 Pasal 18. Hanya saja kebijakan pemerintah yang selalu bersifat sentralistik dan menganggap sebagai lawan bahkan musuh kepada mereka yang memberikan alternatif yang berbeda. Sikap yang cenderung otoriter dari mereka yang berkuasa berakibat terjadi kemandulan dalam segala bidang, apalagi dunia pendidikan sejak Indonesia merdeka relatif diabaikan.

Sementara budaya kemandekan sudah makin mapan, otonomi merupakan suatu keniscayaan yang tidak dapat ditunda akibat kegagalan pemerintahan orla maupun orba. Rasa tidak puas akhirnya memojokkan TNI ${ }^{17}$ dan birokrasi yang tampil sebagai pangreh praja bukan sebagai pamong praja. Masyarakat sudah kehilangan kesabaran dan meminta haknya yang selama ini terpaksa diberikan pada mereka yang berkuasa. Sementara mereka yang berkuasa hanya memperkaya diri dan mengenyangkan para kroninya. Sekalipun otonomi belum merupakan suatu 'keperluan yang wajar', bangsa ini sudah mulai terseret dengan arus globalisasi. ${ }^{18}$ Apabila tidak disiapkan secara bermakna, bangsa ini hanya memasuki era gombalisasi.

Sebenarnya sejak zaman orba telah berlangsung apa yang dikenal otonomi dan desentralisasi sekalipun baru terbatas dalam bidang pendidikan. Inipun terbatas pada bidang pengelolaan SD. Berdasarkan PP no. 25/1951 yang diperkuat UU No.5/1974, pengelolaan man, money, and materials SD diserahkan Pemđa Kabupaten atau Kota. Bupati dan Walikota berwewenang

Hanya saja banyak yang tidak menyenjui pencanuman nama-nama tersebut, dan biasa pula kurang dikenal dalam penyajian sejarah tesmi atau ". . . official history, official detemination that ought to be taught." Lihat selanjutnya Jeannet Henry, "Our Inaccurate Textbooks", dalam Norman R. Yeman dan C. Hoy Steele (Eds), 1973, Majority \& Minority, Allyn and Bacon, Boston. hal. 504 hal. 161

${ }^{16}$ Revrisond Baswir et. al. (eds.), 1999, Pembangunon tanpa Perasaan, Pustaka Pelajar, Idea, dan Elsam, Yogya.

17 Inj terjadi sebagai akibat ABRI yang selama orba 'diperalat' untuk kepentingan Soeharto, kelnarga dan 
memutasikan guru di wilayahnya, sedang mutu akademik dipegang Depdiknas lewat kanwil-kanwilnya. Mutasi guru sering dilakukan karena tingkat nasional sekolah-sekolah mempunyai kelebihan guru s/d 35\%, tapi ketimpangan di tingkat propinsi $47 \%$; di tingkat kabupaten/kota $63 \%$, tapi melonjak $147 \%$ di tingkat kecamatan. ${ }^{19}$ Dari uraian ini jelas otonomi pendidikan yang bertahun-tahun berjalan hanya berisi berbagai penyelewengan dan tidak pernah dibenahi secara serius. Seseorang dapat dengan mudah pindah ke suatu daerah asalkan ada dana khusus, sementara yang benar-benar memerlukan karena tidak ada uang pelicin terpaksa harus nongkrong di suatu tempat. Berbagai penyelewengan yang ada makin menyulitkan upaya untuk meningkatkan mutu pendidikan seperti dalam hal akreditasi program, sertifikasi lulusan, dan penerapan izin kerja. Pentingnya pendidikan sebagai teras keberhasilan otonomi dan desentralisasi sehingga perlu sekali disoroti dalam kajian sub-bagian berikut ini.

\section{C.Pendidikan, Teras Keberhasilan Otonomi dan Desentralisasi}

Sejak kemenangan gerakan reformasi perbaikan pendidikan belum mendapatkan perhatian. Lebih menyedihkan lagi dalam tahun 2001 ini untuk pendidikan hanya disediakan dana sekitar 11 trilyun, sekitar 3,8\% dari APBN yang disetujui DPR. Sementara yang diketahui masyarakat umum kemacetan hutang Liem, salah seorang konglomerat, lebih dari 53 trilyun, sehingga membuat masyarakat makin terperangah. Apalagi dana pendidikan tahun ini (2001) untuk jutaan anak bangsa yang harus dididik dan dicerdaskan hanya disediakan dana sekitar sebelas trilyun. Kebijakan ekonomi yang timpang diperparah dengan kebijakan kesehatan dan pendidikan yang diabaikan. Benarbenar memprihatinkan dana pendidikan yang minim, yang kurang dari seperempat dari dana yang dipinjam dan belum mampu dibayar seorang konglomerat Liem, karena berjumlah lebih dari 53 trilyun.

Selanjutnya penggunaan dana pendidikan yang minim ini sering di luar 'jalur'. Banyak yang mempertanyakan lahirnya proyek-proyek depdikbud, yang tetap dilanjutkan depdiknas. Proyek-proyek ini antara lain berkaitan dengan perubahan kurikulum demi kurikulum yang ada. Ini dapat dilihat dari kurikulum 1995 yang telah disempurnakan pada tahun 1997, dan kurikulum baru tahun 2000. Masyarakat juga dibuat kacau dengan perubahan namanama sekolah. Kalau dulu dikenal dengan nama SMEA maupun STM, sekarang hanya ada SMK. Orang juga mempertanyakan apa manfaat perubahan SMA menjadi SMU?

... SMU perlu diganti dan dikembalikan seperti semula. Istilah umum yang memberikan kesan anak-anak hanya dibekali pengetahuan umum yang artinya 
less and less about more and more until they know nothing about everything. Umum memberikan kesan tidak serius dan tidak ada sambungannya dengan pendidikan tinggi di atas maupun di bawahnya. Pembagian tingkatan pertama dan atas memberikan kesan ada kelanjutan dan kontinyuitas dari proses pendidikan. ${ }^{20}$

Nampak banyak dana pendidikan yang minim ini diperuntukkan hal-hal yang muspro, atau mubazir, atau tidak berguna. Sementara umumnya para guru dan para dosen, terlibat dengan rutinitas yang menjemukan. Apalagi gaji seorang profesor lebih rendah dibandingkan dengan tukang cukur di Yogyakarta. Umumnya tukang cukur Yogya setelah menyelesaikan tugasnya, untuk setiap kepala dia mendapatkan imbalan tiga ribu. Sehari mereka mampu mencukur tiga puluh kepala. Rata-rata mereka mendapatkan penghasilan sebesar lebih dari dua juta lima ratus ribu rupiah setiap bulan. Lebih menyedihkan lagi honor seorang profesor untuk mata kuliah 2 sks, selama 100 menit setiap minggu, selama sebulan hanya menerima Rp. 10.000 dan dikenakan PPH sebesar 15\%. Sementara sekali manggung, grup Project Pop yang beranggota 6 orang, selama $30 \mathrm{~s} / \mathrm{d} 45$ menit dibayar $22 \mathrm{~s} / \mathrm{d} 25$ juta. $^{21}$

Beragam masalah timbul akibat digulirkan otonomi dan desentralisasi, seperti konflik Dayak dengan Madura, pengkaplingan HPH. Bagaimana mengatasinya? Nampaknya kunci utama penyelesaiannya bersumber pada pendidikan yang selama ini diabaikan. Tidak dapat diingkari dari segi kuantitas terdapat kemajuan yang cukup fantastis. Ini nampak dari partisipasi peserta didik tahun 1950 an dan 2000. Terbukti partisipasi peserta didik SD dari 32 $\%$ menjadi $95 \%$, SLTP dari $5 \%$ menjadi $60 \%$, dan SLA dari 3,5\% menjadi $45 \%$, dan PT dari $0,06 \%$ menjadi $11 \% .^{22}$ Hanya saja dalam segi kualitas patut dicarikan pemecahannya. Hancurnya mutu pendidikan antara lain tercermin dari minimnya kemampuan bahasa asing para siswa dan mahasiswa bahkan juga lulusan S1, S2, dan sebagian S3. Sementara pada zaman penjajahan banyak lulusan SD telah menguasai bahasa Belanda dengan baik. Kemampuan lulusan SMU masa itu antara lain tercermin dari kutipan berikut ini:

Selain bahasa Inggris [dan bahasa Belanda] yang merupakan mata pelajaran atau bahasa wajib, masih ada dua bahasa lagi yang bersifat fakultatif, yaitu bahasa Perancis dan Jerman yang dua-duanya saya ambil. Pembaca dapat membayangkan empat bahasa sekaligus. ${ }^{23}$

Indra Samego et. al., 1998, Bila ABRJ Berbisnis, Mizan, Bandung.

${ }^{1 *}$ Lihat paper yang disajikan dalam acara sarasehan anggota senat Universitas Negeri Yogyakara pada 4 November 2000, atau Mukminan, 2000. "Pendidikan Pengetahuan Sosial di Era Global" pada 28 Oktober

1" T. Raka Joni, op. cit., hal. 1 
Hanya saja tidak semua sistem pendidikan Belanda patut dijadikan contoh, ${ }^{24}$ sama halnya dengan pendidikan Barat pada umumnya. Dampak pendidikan Barat jelas terlukis dari penggunaan narkoba, merosotnya moral, dan wabah veneral diseases serta makin banyaknya anak-anak yang lahir di luar nikah. Memang sebagian tetap bersitegub dengan kehebatan pendidikan Barat, tetapi sebagian pakar pendidikan Barat sendiri dalam kegalauan, hal ini antara lain tercermin dalam uraian berikut ini:

Or would modern civilization be able to regenerate itself and move toward a world-wide civilizarion that could manage to achieve a more just, humane, and equitable condition of life for the peoples of the world? Much depends upon the role that education plays in the future. Will western education become formalistic, congealing, constricted, and isolated as education became in the dispersive periods of Mesopo-tamian and Egyptian education?25

Jelas beragam kelemahan pendidikan Barat dan akibatnya yang menghancurkan masa depan generasi muda secara tidak langsung dengan 'amukan' narkoba dan aids. ${ }^{26}$ Selain itu ada pula pemusnahan langsung generasi muda lewat pembunuhan yang dilakukan kaum remaja yang berusia di bawah 19 tahun, yang akan diberikan berbagai contohnya. Walaupun demikian masih banyak para pengagumnya di Indonesia, dan lahirlah berbagai sekolah plus yang menggunakan bahasa Inggris sebagai bahasa pengantar. Fuad Hassan sebagai mantan Mendikbud menilai sekolah-sekolah plus tersebut sebagai katup pengaman karena rendah dan tertinggalnya pendidikan di Indonesia. ${ }^{27}$

Hanya saja dalam kaitan ini perlu direnungkan peringatan Margareth Marcus, seorang perempuan Yahudi yang lahir dan dibesarkan di New York, USA. Hanya saja Miss Marcus mempunyai pemikiran tercerahkan oleh berbagai bacaannya, ini antara lain dibuktikan dengan penilaiannya yang cukup jernih mengenai pendidikan dan mass media Barat, seperti disajikan terjemahannya berikut ini: "Senjata-senjata yang paling kuat dari imperialisme kultur Barat adalah sistem pendidikannya dan media massa, radio, televisi

"Miftah Thoha, 2001. "Manajemen Pendidikan di Era Otonomi Daerah”, makalah Semunar Nasıonal Reformasi Penódikan Nasional 16-17 Maje!, hal. 6

"Rita Trjana Budiarti. 2001, "Manajemes Tu Wa Ga Pal". Galra. 17 Marer. hat. 62

:Soedijaro, 2001. "Keperluan Dana unuk Pendidikan dan Implikasinya”, makalah Semunar Nasional Reformasi Pendidikan Nasıonal 16-17 Marel, ha!. 2

? R Koestedjo. 1996. Inilah Jolan Hiduphu. Rosda Jayaputra, Jakana, haj. 20

2* Salah san contoh hasil negatif dari pendidikan Belanda dapat dilihat kebiasaan ibu rumah sangga Belanda yang membuang kepingan-kepingan rov sebanyak 79.000 ton pada tahun 1970. Sementara jucaan manusia di berbagai negara lain menjigga] karena kelaparan. (Lihat Elza Peld1 Taher, 1985. “Islam di Tengah Pudamya Agama dan Runtuhnya Martabat Manusia", dalan Agama dan Kekerasan. Jakara: Kelompok Sndi Prokjamasi dan The Asia Foundation, hal, 43l.)

${ }^{25} \mathrm{R}$. Freeman Butts, 1973. The Educarion of the West. McGraw-Hitl Book Co.. New York, hal. 564

2 Dalarn kasus ALDS di USA, ada baknya dukaji uraian berikut ini: Sekarang unu sekitar sacu juta orang Amenka 
dan pers yang populer, dalam mana warisan artistik dan spiritual yang asli dari Asia hampir tidak dapat dipertahankan. "28

Beberapa problema pendidikan Barat yang menafikan peran agama, tergambar dari berbagai budaya membunuh seseorang yang dipandang sebagai lawan. Ini antara lain tercermin dalam beberapa tragedi yang dilakukan para siswa sekolah menengah. Charles Andrew Williams, 15 th., menggunakan pistol kaliber 22 milik ayahnya, Charles Jeffrey Williams. Andrew telah membunuh Byran Zuckor, 14 tahun; dan dua siswa lain serta melukai seorang petugas keamanan. Andrew berasal dari Knoxville, Maryland, sering diejek teman-temannya karena potongan rambutnya, badannya yang ceking, atau minimnya kemampuan skateboardnya di Santana High School, California.

Hal yang sejenis dan lebih mengerikan telah dilakukan dua siswa Columbine High School, pinggiran Denver, Colorado. Tembakan dua siswa remaja tersebut telah menewaskan 12 temannya, seorang guru, dan 23 lainnya luka2; kemudian keduanya bunuh diri. Peristiwa mengenaskan yang sulit dicari penyebabnya ini terjadi pada April 1999. Sementara itu seorang gadis, 14 tahun, đi Williamsport telah menembak bahu temannya. Setiap tahun sejumlah 8000 orang dibunuh anak-anak di bawah usia 19 tahun, dan setiap pekan seorang anak ditangkap karena membawa senjata ke sekolah. Ada pula anak yang merencanakan menaruh bom di meja gurunya. ${ }^{29}$ Nampaknya tragedi yang mengenaskan ini telah menjadi menu rutin dan sering terulang dan terakhir pada 22 Maret 2001 dilakukan Jason Hoffman yang berusia 18 tahun. Dengan dua pistol dia secara membabi buta telah menembaki teman-teman dan gurunya di Granite Hjlls High School, sehingga melukai dua guru, Frau Zumwalt 47 tahun, dan Priscilla Murphy 53 tahun; dan tiga siswa, Shaundra Hughes 17 tahun, Toby Halststead 15 tahun, dan Andy Yafuso.

Jelaslah pendidikan yang bermakna haris memadukan peranan wahyu dan ilmu sebagai teras utama aktivitas pendidikan. 'Penekanan ilmu umum, dan mengabaikan peranan agama, dapat melahirkan sikap nyleneh. Salah satu contohnya dilakukan puteri yang cerdas karena mempunyai IQ 170. Dialah Melissa, gadis cantik dan berbakat. Dia telah pandai menulis serta membaca sejak berusia 18 bulan. Sayangnya bakat alami ini telah membuahkan malapetaka karena Melissa dididik tanpa mengenal sentuhan agama yang bermakna.

Dalam usia 14 tahun dia masuk Harlow College, dan ketika berusia 17 tahun dia telah belajar di Oxford College. Di lembaga bergengsi ini Melissa belajar ekonomi, filsafat serta politik. Semua kejayaan ini diperolehnya karena 
mudahnya dia mendapatkan nilai A. Ibunya, Jane, dan nenek Melissa sendiri sangat membantunya, walaupun dia termasuk kuper, kurang pergaulan, dan kurang aktif berolah raga serta hal-hal sejenis lainnya. Melissa benar-benar hidup terasing dari masyarakat sekitarnya.

Akibat kurangnya menghayati pendidikan agama, seringkali di hadapan berbagai pria yáng tidak dikenalnya, tanpa segan-segan Melissa akan menanggalkan pakaiannya satu persatu. Selanjutnya dia akan meliuk-liukkan badannya. Menariknya Melissa tidak merasa malu, bahkan berkata:

Saya perlu dan ingin sekali menari telanjang karena saya menikmati perhatian yang saya dapatkan. Saya senang orang-orang menyatakan saya indah dan luar biasa. Saya merasa seperti sesosok dewi seks yang memikat. Saya tahu, saya penari telanjang fantastik. Sungguh menyenangkan bila tahu bahwa anda betul-betul hebat pada suatu hal. ${ }^{30}$

Contoh di atas merugikan citra dunia pendidikan. Ini dapat terjadi karena sistem pendidikan yang ada kirang memperhatikan agama dan tidak transparan. Sistem pendidikan yang berlaku lebih mengutamakan pendekatan kuasa, serta bukan menyemaikan pendekatan budaya. Sistem pendidikan demikian nampaknya sejalan dengan uraian Burgett: "Our school systems are autocracies built on the foundation of arbitrary power, underfined standards, unrealistic curricula and unsupervised teachers. Schools perpetuate a world of fantasy having little relation to the real world". ${ }^{11}$ Dengan reformasi pendidikan hal demikian dapat dicegah dan diarahkan pada sesuatu yang bermakna.

Pembenahan pendidikan secara bermakna mampu pula menjawab tantangan banyaknya wanita karier dalam bidang pendidikan, yang melahirkan berbagai problema baru, seperti “ . . tingkat kemangkiran karyawati yang sudah menikah, apalagi jika mempunyai beberapa orang anak, memang cenderung lebih tinggi dibandingkan dengan para karyawan". Masalah ini dapat diatasi dengan jam yang fleksibel, atau menyediakan tehnologi yang canggih, baik dengan faks atau penggunaan komputer yang on line. Dengan demikian sebagian aktivitas kuliah atau kerja dapat diselesaikan di rumah, asalkan setiap saat dapat dihubungi. ${ }^{32}$ Hanya dengan berbagai krisis yang belum teratasi, apalagi krisis ekonomi, mungkin semua ini masih berupa angan-angan saja.

Kalau tidak ada pembenahan pendidikan, dan mengabaikan agama, akan berakibat fatal sekalipun dari segi pencapaian ilmu cukup memadai. Contohnya, Melissa berhasil dengan ujian-ujian yang ditempuhnya, tetapi dia memutuskan beristirahat kuliah selama setahun. Dia terpaksa bekerja

\footnotetext{
Refleksi Amien Rais, hal. 81

"2 Pusat Data dan Analisa Tempo. 2001, "Sekolah Plus Pintu Gerbang ke Luar Negeri?", Tempo, 18 Maret, hal. 68

2n Maryam Jamilah. Islam dalam Kancah Modernisasi, diambilkan dari Sapto Raharjo, "Generasi Muda,
} 
merawat orang jompo dan menjadi instruktur aerobik. Kesukaran uang telah memaksanya menjadi penari di Windmill Club di London. Akhirnya Melissa berhasil menjadi stripper penuh dan mendapat julukan Naughty Oxford Totty. Dia merasa ditertawakan penonton, tapi “... ketika mereka bertepuk tangan dan bersorak sorai, saya merasa hebat". Akhirnya dia benar-benar berhenti kuliah serta berkata: "Saya tidak mau jadi korban Oxford lagi, saya lebih senang menjadi penari telanjang yang bahagia daripada menjadi mahasiswi yang sengsara". ${ }^{33}$ Sebagai bangsa yang terpesona oleh peradaban dan pendidikan Barat, berakibat memptihatinkan seperti yang dialami bangsa Indonesia saat sekarang ini. Hal sejenis ini nampaknya berlaku di sebagian besar negara-negara yang mayoritas penduduknya beragama Islam. Untuk lebih jelasnya tolong dikaji rintihan berikut ini:

. . keadaan umat Islam yang tak kunjung terbebaskan dari berbagai kekacauan dan penindasan. Betapa tidak, hasil bumi dan kekayaan negeri mereka dirampok; haram bagi mereka dan halal bagi imperialis. Negara mereka, secara ekonomi ataupun politik boleh dikuasai oleh siapa pun yang menghendakinya. Umat Islam bagaikan orang asing di numah sendiri, gelisah tidak merasa tenteram tinggal di negerinya, dan terlarang untuk menikmati kelezatan hasil bumi milik mereka sendiri. ${ }^{34}$

Sebagai mayoritas penduduk Indonesia, ${ }^{35}$ sudah semestinya apabila umat Islam menampilkan berbagai pemikiran yang berkaitan dengan pembenahan pendidikan. Ilmu sebagai bagian dari pendidikan sendiri terasa demikian 'beragam' dalam salah satu suguhan yang disajikan al Qur'an. Ini antara lain telah disajikan dalam disertasi Imam Syafi' ie yang diterbitkan. ${ }^{36}$ Ada beragam istilah yang langsung dan tidak langsung berkaitan dengan ilmu. Masingmasing istilah nampaknya mempunyai makna yang khas yang sering sekali sulit diterjemahkan secara utuh. ${ }^{37}$

Untuk pembenahan pendidikan dalam mensukseskan otonomi dan desentralisasi, ada baiknya disosialisa'sikan secara utuh beragam kandungan al Qur'an mengenai ilmu baik dalam konteks ta'lim, tarbiyah maupun $t a$ 'dib. Sayangnya kajian al Qur'an sering lebih dikaitkan dengan Tuhan bukan dengan

Islam, Musik, dan Rock", dalam Jabrohim dan Saudi Berlian, 1995, Islam don Kesenion, Yogya: Majelis Kebudayaan Muhammadiyah UAD dan Lembaga Litbang PP Muhammadiyah, hal. 54

2" Purwani Diyah Prabandari, 2001, "Bocah-bocah yang Memanggul Senjata", Tempo, 18 Maret, hal. 108

30 I Gede Agung Yudana, 1998, "Ulah 'Miring' Alibat Cirta Bersyarat", dalam Intisari, Februari, hal. 134

${ }^{31}$ W. A. Burgeth, 1970, We Have Failed the Schools, Vantage Press, New York.

${ }^{32}$ Sondang P. Siagian, 1994, Parologi Biroknasi Analisis, Identifikasi dan Terapinya, Ghalia Indonesia, Jakarta. hal. 29-30.

J I Gede Agung Yudana, op. cit., hal. 137

${ }^{14}$ Selanjutnya lihat Mustofa Muhammad Asy-Syak"h, 1995, “Islamu Bi Laa Madzaahib, a.b. A. M. Basalamah, Islan Tidak Bermazhab, Gema Insani Press, Jakarta. hal. 17

${ }^{35}$ Dalam zaman penjajahan Islam biasa diidentikkan dengan pribumi sejalan dengan kalimat berikut ini: "Islam 
peranan yang seharusnya dimainkan manusia selaras ajaran wahyu Allah. ${ }^{38}$ Dalam hal ilmu cukup menarik pula uraian berikut ini:

Teori pengetahuan burhaani (al-Baqarah ayat 111) dapat didefinisikan sebagai metodologi penalaran ilmiah atau empirik. Selain itu al-Qur'an mengenaikan tiga teori pengetahuan lainnya, yaitu: Bayaani adalak pengetahuan tentang kebenaran yang diperoleh dari keterangan atau penjelasan bayan (wahyu), 'iffaani adalah pengetahuan tentang kebenaran (hakikat) yang diperoleh melalui gerakan zuhud, tirakat, dan bentuk-bentuk olah spiritual lainnya, sedang amaani adalah pengetahuan tentang kebenaran yang diperoleh melalui anganangan khayalan. ${ }^{39}$

\section{Penutup}

Dari uraian yang telah disajikan terasa pentingnya digulirkan otonomi dan desentralisasi. Hanya saja banyak yang meragukan keberhasilan otonomi dan desentralisasi tanpa persiapan yang matang. Dengan digulirkan otonomi tanpa demokrasi serta pembenahan pendidikan yang menyeluruh hanya akan memindahkan otoritarianisme pusat ke daerah. Setelah berhasil melengserkan seorang Soeharto di tingkat pusat, justru melahirkan puluhan tiran di tingkat propinsi, dan ratusan tiran di kabupaten serta kodya. ${ }^{40}$

Dengan otonomi dan disentralisasi yang berteraskan pendidikan, bermakna sekurang-kurangnya pemerintah akan melaksanakan kebijakan yang mementingkan pendidikan. Ini sejalan pula dengan apa yang disajikan dalam amanat proklamasi dan Pembukaan UUD 1945 serta TAP MPRS No. XXVII/ 1966 yang menetapkan anggaran penididikan sebesar 25\%. Apabila hal ini menjadi suatu kenyataan, mungkin akan terjadi suasana yang bermakna dalam kehidupan guru dan karyawan pada umumnya, seperti gambaran berikut ini:

. . para guru dapat bekerja dengan tenang tanpa harus berusaha mencari nafkah tambahan untuk hidupnya dan . . pada saat anak-anak secara leluasa dapat bermain di jalan-jalan desa, dan alun-alun belum berubah menjadi kawasan pertokoan dan stasiun bis, pada saat pegawai/karyawan masih bisa tidur siang dan dapat menikmati teh di sore hari. ${ }^{41}$

Tentunya masalah pendidikan tidak hanya masalah dana saja, tetapi bagaimana segera diwujudkan sistem pendidikan yang lebih berorientasi pada pendekatan populis bukan elit. Yang lebih penting lagi bagaimana pendidikan akan melahirkan beragam creative minority yang mampu menyelesaikan masalah. Bagaimana memantapkan peranan wahyu dan ilmu dalam pendidikan,

can be described as 'everything the native can identify as his own territory'. When a trading association rejoices in the predicate 'Islamijah', this does not mean that it stands on the basis of the Muslim faith, but that it is a national, rative association." Anthony J.S. Reid, 1974, Indonesian National Revolution 1945-50. Dai Nippon Printing Co.,Hongkong, hal. 4

35 Imam Syafi'ie, 2000, Konsep llmu Pengetahuan dalam al-Qur'an, UII Press, dan MSI UII, Yogya. 
sehingga nantinya mampu melahirkan manusia seperti yang dicita-citakan Iqbal, yang tersajikan dalam bait-bait berikut ini:

Kau menciptakan malam dan aku yang membuat pelita

Kau menciptakan tanah liat dan aku yang membuat piala

Kau menciptakan sahara, gunung-gunung dan hutan belantara

Aku juga membuat kebun anggur, taman-taman dan padang tanaman.

Akulah yang mengubah batu menjadi cermin

Akulah yang mengubah racun menjadi obat penawar. ${ }^{42}$

Dengan demikian para lulusan lembaga pendidikan tidak hanya menjadi para pencari pekerjaan, tapi mereka tampil sebagai pencipta pekerjaan. Sebagian dari mereka akan tampil sebagai wiraswasta yang ingin mengubah masyarakatnya sejalan dengan cita-citanya yang bermakna. Akan muncul beragam wiraswasta tanpa uluran tangan dari pihak penguasa serta sejenisnya. Selanjutnya akan muncul berbagai wiraswasta yang dikagumi, tanpa KKN atau sejenisnya, serta sebagian dapat muncul sebagai konglomerat. ${ }^{43}$ Apabila otonomi dan desentralisasi berteraskan pendidikan wujud, tak akan ada mereka yang berkuasa yang asyik bercanda dengan malima dan membelakangi lima wa, yaitu wareg (kenyang), wastra (pakaian), wisma (rumah), waras (sehat), dan wasis (pandai) untuk kepentingan bangsa. Lima wa ini diketengahkan Petruk dalam "Wahyu Purba Kayun". ${ }^{44}$ Sebagian penguasa tidak cenderung membonsainya sehingga tinggal apa yang dikenal sebagai pangan, sandang, dan papan. Kedangkalan sebagian yang berkuasa yang cenderung membonsai sesuatu yang menjadikan mereka merasa dibebani dan tidak memahami tugas yang seharusnya mereka emban sebaik-baiknya ${ }^{45}$, akan dapat dikurangi secara bertahap.

Semoga pemikiran awal dapat menjadi pemangkin bagi gagasan lain yang lebih bermakna dan segera dapat disajikan, lebih beruntung lagi kalau dapat segera diamalkan. Terima kasih.

${ }^{37} \mathrm{Ibid}$, hal. 30-38. Untuk kajian lebih lanjut silahkan dibaca pula Mansoer Malik, 1989, "Metode Penalaran IJmiah dalam al-Qur'an", disertasi IAIN Syarif Hidayatullah, Jakarta, maupun M. Zainuddin, 1992 "Ilmu dalam Perspektif Islam", Tesis IAIN Sunan Sunan Kalijaga; Yogyakarta,

3" Ahmad Syafii Maarif, 1995, Membumikan Islam, Pustaka Pelajar, Yogya, hal. 4

${ }^{39}$ Ali Zawawi dan Saifullah Ma"shum, 1999. Penjelasan Al-Qur'an tentang Krisis Sosial Ekonomi dan Politik, GIP. Jakarta, hal. 87

"Pratikno, op. cit., hal. 9

${ }^{41}$ Soedijarno, op. cit., hal. 2

42 Ali Audah, 1999. Dari Khasanah Dunia Islam, Firdaus, Jakarta, hal. 34

${ }^{4}$ Salah seorang profil pengusaha pribumi sukses tanpa fasilitas, antara lain nampak dalam tokoh Achmad Bakrie, sayangnya prestasi ini kurang dikenal luas. Selanjutnya lihat Syafnudin Pohan dkk , 1992, Achntad Bakrie Sebuah Porret Kerja Keras, Kejujuran dan Keberhasilan, Jakarta: Kelompok Usaha Bakrie. 


\section{DAFTAR PUSTAKA}

Amir, Hazim, 1991, Nilai-nilai Etis dalam Wayang, Pustaka Sinar Harapan, Jakarta.

Asy-Syak, Mustofa Muhammad,1995, “Islamu Bi Laa Madzaahib, a.b. A. M. Basalamah, Islam Tidak Bermazhab, Gema Insani Press, Jakarta.

Audah, Ali, 1999, Dari Khasanah Dunia Islam, Firdaus, Jakarta.

Baswir, Revrisond et. al. (eds.), 1999, Pembangunan Tanpa Perasaan, Pustaka, Yogya.

Burgett, W. A., 1970, We Have Failed the Schools, Vantage Press, New York.

Butts, R. Freeman, 1973, The Education of the West, McGraw-Hill Book Co, New York.

Budiarti, Rita Triana, 2001, "Manajemen Tu Wa Ga Pat”, Gatra, 17 Maret

Dwiyanto, C.f. Agus, 2000, "Membangun Sistem Pelayanan Publik yang Memihak pada Rakyat", makalah Seminar Nasional Profesionalisasi Birokrasi dan Peningkatan Kinerja Pelayanan Publik, diselenggarakan Jurusan Ilmu Administrasi Negara, FisipoI UGM, 29 April

Fukuzawa, Yukichi, "Encouragement of Learning", alih bahasa Arifin Bey, Jepang Di antara Feodalisme dan Modernisasi, Pantja Simpati, Jakarta.

Henry, Jeannet, "Our Inaccurate Textbooks", dalam Norman R. Yetman dan C. Hoy Joni, T. Raka, 2001, "Permasalahan Kritikal Pengelolaan Ketenagaan Guru dalam Kerangka Pikir Desentralisasi", Seminar Komisi Reformasi Pendidikan Nasional 16-17 Maret

Kuntowijoyo, 1985, Dinamika Sejarah Umat Islam Indonesia, Shalahuddin Press, Yogya.

M. Zainuddin, 1992 "Ilmu Dalam Perspektif Islam”, Tesis IAIN Sunan Sunan Kalijaga, Yogyakarta.

Maarif, Ahmad Syafii, 2001, "Landasan Pendidikan Indonesia Masa Depan", Makalah Disampaikan dalam Seminar Reformasi Pendidikan Nasional, di UNY, 16-17 Maret.

Mukminan, 2000, "Pendidikan Pengetahuan Sosial di Era Global" pada 28 Oktober 
Numberi, Freddy, 2000, “Organisasi dan Administrasi Pemerintah”, Makalah yang Disajikan dalam Seminar Nasional Profesionalisasi Birokrasi dan Peningkatan Kinerja Pelayanan Publik, Diselenggarakan oleh Jurusan Ilmu Administrasi Negara, Fisipol, UGM, 29 April

Prabandari, Purwani Diyah, 2001, “Bocah-bocah yang Memanggul Senjata”, Tempo, 18

Pusat Data dan Analisa Tempo, 2001, "Sekolah Plus Pintu Gerbang ke Luar Negeri?", Tempo, 18 Maret

Pohan, Syafrudin dkk ,1992, Achmad Bakrie Sebuah Potret Kerja Keras, Kejujuran dan Keberhasilan, Jakarta: Kelompok Usaha Bakrie

Pratikno, 1999, "Hubungan Pusat Daerah Pasca Orba Analisis Awal terhadap UU No. 22/1999 dan RUU No. 23/ 1999", makalah dalam diskusi panel KMAN Fisipol UGM, 27 Mei

R. Koestedjo, 1996, Inilah Jalan Hidupku, Jakarta: Rosda Jayaputra

Raharjo, Sapto, 1995, “Generasi Muda, Islam, Musik, dan Rock”, dalam Jabrohim dan Saudi Berlian, Islam dan Kesenian, Yogya: Majelis Kebudayaan Muhammadiyah UAD dan Lembaga Litbang PP Muhammadiyah

Rais, M. Amien, 1997, Refleksi Amien Rais, Gema Insani Press, Jakarta.

Rais, M. Amien, 1997, Demi Kepentingan Bangsa, Pustaka Pelajar, Yogya. Rakhmat, Jalaluddin, 1998, Islam Aktual, Mizan, Bandung.

-.----, 1998, Islam Alternatif, Mizan, Bandung.

Reid, Anthony J.S., 1974, Indonesian National Revolution 1945-50, Dai Nippon Printing Co., Hongkong.

Samego, Indra et. al., 1998, “. . Bila ABRI Menghendaki”, Mizan, Bandung.

Samego, Indra et. al., 1998, Bila ABRI Berbisnis, Mizan, Bandung.

Sanit, Arbi, 1998, Reformasi Politik, Pustaka Pelajar, Yogya.

Shihab, M. Quraish, 1996, Wawasan al Qur'an, Mizan, Bandung.

Sairin, Sjafri, 2001, “Otonomi Daerah: Jerat-jerat Kultural”, Gatra, 3 Maret

Steele (Eds), 1973, Majority \& Minority, Allyn and Bacon, Boston.

Soedijarto, 2001, "Keperluan Dana untuk Pendidikan dan Implikasinya", makalah Seminar Nasional Reformasi Pendidikan Nasional 16-17 Maret 
Siagian, Sondang P., 1994, Patologi Birokrasi Analisis, Identifikasi dan Terapinya, Ghalia Indonesia, Jakarta.

Syafi' ie, Imam, 2000, Konsep Ilmu Pengetahuan dalam al-Qur'an, UII Press, dan MSI UII, Yogya.

Thoha, Miftah, 2001, "Manajemen Pendidikan di Era Otonomi Daerah", makalah Seminar Nasional Reformasi Pendidikan Nasional 16-17 Maret

Taher, Elza Peldi, 1985, "Islam di Tengah Pudarnya Agama dan Runtuhnya Martabat Manusia", dalam Agama dan Kekerasan, Kelompok Studi Proklamasi dan The Asia Foundation, Jakarta.

Wijayanto, Gatot, 2000, “Aparatur Yang Bersih, Pemimpin Yang Rela Berkorban dan Menderita Kunci Keberhasilan Otonomi Daerah", makalah Seminar Pati Menyongsong Otonomi Daerah Tahun 2001, 20 November

Yuliantara, Dadang (Penyunting), 2000, Arus Bawah Demokrasi, Lepara Pustaka Utama, Yogya.

Yudana, I Gede Agung, 1998, "Ulah 'Miring' Akibat Cinta Bersyarat", dalam Intisari, Februari

Zawawi, Ali dan Saifullah Ma'shum, 1999, Penjelasan Al-Qur'an tentang Krisis Sosial Ekonomi dan Politik, GIP, Jakarta. 